\title{
Dynamic Marketing and Service Innovation for Service Excellence
}

\author{
Evo S. Hariandja, *Togar M. Simatupang, Reza A. Nasution, and Dwi Larso \\ School of Business and Management, Bandung Institute of Techmology (ITB), Indonesia
}

\begin{abstract}
This study aims at creating a framework describing how the interaction capabilities between dynamic marketing and service innovation can influence service excellence. In this study market sensing, market learning, market targeting or positioning are classified as dynamic marketing capabilities (DMC), while sensing, seizing, and transformi ng are classified as service innovation capabilities (SIC). Hence, the drivers of service excellence for the framework being developed are divided into three main categories: dynamic marketing capability, service innovation capability, and their interaction. The findings of the study on three hotels, ranging from 4-star to 5-star hotels and operating in Indonesia, suggest that both capabilities and their interaction play their roles in achieving service excellence.
\end{abstract}

\begin{abstract}
Abstrak: Riset ini bertujuan untuk menciptakan kerangka yang menggambarkan bagaimana kapabilitas interaksi antara pemasaran dinamik dan inovasi jasa dapat mempengaruhi keunggulan layanan. Dalam riset ini, penginderaan pasar, pembelajaran pasar, target pasar serta positioning diklasifikasikan sebagai kapabilitas pemasaran dinamik (DMC), sementara penginderaan (sensing), merebut (seizing), dan transforming diklasifikasikan sebagai kapabilitas inovasi jasa (SIC). Oleh karena itu, penggerak keunggulan layanan untuk kerangka yang dikembangkan dibagi menjadi tiga kategori utama: kapabilitas pemasaran dinamik, kapabilitas inovasi jasa, dan interaksi diantara kedua kapabilitas. Temuan studi pada tiga hotel yang dijadikan sebagai studi kasus di hotel bintang 4 (empat) dan 5 (lima) yang beroperasi di Indonesia, menunjukkan bahwa kedua kapabilitas dan interaksinya memainkan peran mereka dalam mencapai keunggulan layanan.
\end{abstract}

Keywords: dynamic marketing capability; hotel industry; interaction; service innovation capability; service excellence

* Corresponding author's e-mail: evo.hariandja@sbm-itb.ac.id 


\section{Introduction}

Research into the capability interaction between marketing and innovation has mostly been disregarded (Moorman and Slotegraaf 1999). Innovation capability has become a critical component of a firm's marketing capability if it intends to maintain its long-term performance (Atuahene-Gima 1996). A study conducted by Ngo and O'Cass (2012) and Tushman (1997) concluded that long-term success is not assured by innovation only. A firm will likely leverage its innovation capabilities if it possesses better market-related capabilities in servicing its market, new market entry, and customers with greater value. Under the concept of complementary capability, combining the capabilities results in enhancing a firm's performance. (Song et al. 2005). Recent studies have shown that a capability interaction between marketing and innovation affects performance-based customers (O'Cass and Ngo 2011; Ngo and O'Cass 2012). In this context, marketing and innovation are perceived as complementary to improve a synergistic market performance.

The study of the capability interaction between innovation and marketing has still not been explored very much, especially in the hospitality industry. A study conducted on manufacturing firms by Sok and O'Cass $(2010,2011)$ has shown that complementary capability between innovation and marketing is positively related with performance. Interfunctional coordination and interaction between marketing and innovation can exist in the sharing of market information that is crucial for substantially new service development in the service context (Henard and Szymanski 2001; Im and Workman 2004). However, that study has not yet explored the interaction capability on service excellence in the hotel industry. Since service excellence plays an important role in the hotel industry, it must adapt continuously to a dynamic market. This study thus aims to explore the above mentioned research gap via two research objectives: to create a framework describing how dynamic marketing capability and service innovation capability can influence the service excellence and to investigate the capability interaction that can be formulated in a hospitable context in order to achieve service excellence.

This paper is organized as follows. First, it presents a literature review on dynamic marketing and service innovation capability, the capabilities interaction, and service excellence. Second, it discusses the development of the conceptual framework that illustrates the capability interaction in achieving service excellence. Third, it discusses the research methods. Fourth, it present the findings of three case studies. Fifth, it discusses the capabilities related to service excellence. Finally, it presents the conclusion of the results of qualitative study.

\section{Literature Review}

The dynamic marketing capability (DMC) concept arises from the strategic management theory and provides a new interpretation of how companies in the environment that change rapidly obtain their competitive advantage (Winter 2003; Teece et al. 1997). Hooley et al. (2008) defined the dynamic marketing capability as the ability to create new resources, identify, respond to and exploit changes and classified them into market sensing, learning, and market targeting or positioning. This market sensing capability is a firm's ability to learn from their customers, collaborators, and competitors in order to sense, process, and use information as well as to act continuously on trends and events 
in prospective and present markets (Day 1994; Kok et al. 2003).

The learning capability enables firms to maintain long-term competitive advantages over their rivals, to survive in dynamic and competitive environments, and to be receptive to acquiring and assimilating external knowledge (Hooley et al. 2008). This learning capability enables them to identify new opportunities, and to allow for repetition to integrate information from the external environment in pursuit of improved effectiveness (Zollo and Winter 2002).

Market targeting or the positioning capability is a firm's ability to identify alternative opportunities and then select appropriate market targets that are aligned for the best effect. Aligning resources and capabilities with changing markets needs to take account of the marketing competencies.

\section{Service Innovation Capability (SIC)}

Service innovation is defined as a new or significantly improved service concept that is taken into practice (TEKES 2009). Gadrey et al. (1995) stated that service innovation is the variations in product delivery that cause an appreciation in the service experience for consumers. This study adopts the study of Pöppelbuß et al. (2011) that SIC contains sensing, seizing, and transformation components. Sensing refers to the identification of the need to change service operations or opportunities; seizing refers to exploring and selecting feasible opportunities for change; and transformation is concerned with the new service implementation. In line with this perception, the models of new service development, service innovation, or service design can be seen as the dynamic capability of service innovation.

\section{Capability Interaction Between Dynamic Marketing and Service innovation}

Interaction is synonimous with contact, interface, relations, and communication which has a mutual, reciprocal action or influence between two actors in an organization (Backstrand 2007). Thompson's (1967) classification of interfunctional interface consists of a pooled, sequential, and reciprocal interface. Pooled interface means that each part makes a discrete contribution to the whole and not necessarily depends on or supports every other part directly. Sequential interface is a serial relationship where the output of a part is the input of another one. Reciprocal interface is a relationship where the outputs of each part become the inputs for the others. Thus each unit is penetrated by the others.

Song et al. (2005) defined interaction as the complementary capabilities and competencies between technological and marketing aspects. According to Atuahene-Gima (1996), innovation capability (IC) is an important complement to marketing capability (MC) where an organization in pursuit of specific market opportunities but does not innovative, finds it impossible to maintain its longterm performance. Innovation alone does not provide an assurance of long-term success but a firm must have the ability to market its offerings effectively (Ngo and O'Cass 2012). The key to long-term business success is not necessarily by innovations itself (Tushman 1997). To enter new markets, serve markets better, or provide greater value than rivals, a firm can leverage its innovation capabilities only if it possesses market-related capabilities (Garud and Nayyar 1994; Hult and Ketchen 2001). Song et al. (2005) argued that better results are achieved through capabili- 
ties that combine effectively to enhance performance.

Vorhies and Morgan (2005) showed that the effect of capabilities on the result is the greatest. Complementary capabilities can increase the firm's effectiveness and/or efficiency (Milgrom and Roberts 1990; Moorman and Slotegraaf 1999; King et al. 2008). The complementarity between innovation and marketing has been acknowledged (Drucker 1954). Although the studies exploring the effects of innovation capability, marketing capability, and their interaction on performance have been done ( $\mathrm{Ngo}$ and O'Cass 2012; O'Cass and Ngo 2011), research on their interaction on service excellence is still to be done. Capability theorists seek to explain how the combinations of resources and capabilities can be developed and deployed in response to dynamic business environments (Teece et al. 1997).

In this study, service innovation and dynamic marketing are seen as complementary in that they synergistically improve service excellence. It is contended here that DMC and SIC have greater synergy when combined to achieve common outcomes, and that their integration results in service excellence (SE).

\section{Service Excellence}

Organisations are increasingly providing service excellence as an integral part of their superior service to win the customers' hearts and stay competitive in the market (Berry and Parasuraman 1992). Service excellence, which is viewed as being "easy to do business with" (Johnston 2004), delivers promises and is an expression of very high satisfaction (Oliver 1997). This suggests that the service organization does not only need to satisfy the customers but has to delight them as well (Aziz and Wahiddin 2010).

Service excellence in this study is based on service delivery, servicescapes, customer participation, and customer responsiveness. Flexibility and customization in service process and delivery are highly appreciated by customers (Bettencourt and Gwinner 1996). Well planned and designed service delivery may directly contribute to the whole service excellence. Servicescape is related to the style and appearance of the physical atmosphere and environment in a service organization that has some impacts on customers' experience (Lovelock et al. 2005). Dube and Renaghan (2000) also confirmed the importance of architecture and design as key value drivers that influence the customers' perceptions of service excellence.

Customers' participation increasingly plays an active and even a leading roles in service production and delivery processes (Xue and Harker 2002) in most of the service organisations. The nature of service characteristics that is highly simultaneous requires customers to be part of the service transaction or act as a co-producer. The customer's engagement with the service as a co-producer is important in the cost reduction and service quality improvement process (Heskett et al. 1997). Thus, the degree of service success may depend very much on the customer's participation to make the service happen. In other words, in some services, the customer is acting as a partial employee of the organization.

\section{Conceptual Framework}

The above mentioned literature overview on DMC and SIC indicates that there are three distinct activities for each capabil- 
Figure 1. Conceptual Framework for DMC, SIC, Interaction DMC and SIC, and SE

\begin{tabular}{|l|l|}
\hline \multicolumn{2}{|l|}{ Service Excellence (SE) } \\
\hline \begin{tabular}{|l|l|}
\hline \\
Dynamic marketing capability \\
-Market sensing \\
-Learning \\
-Market targeting and posi- \\
tioning
\end{tabular} & $\begin{array}{l}\text { Service innovation capability } \\
\text { (SIC) } \\
\text { Interaction between } \\
\text { DMC and SIC } \\
\text {-Sensing } \\
\text {-Seizing } \\
\text {-Transforming }\end{array}$ \\
\hline
\end{tabular}

ity that influence the service excellence (also shown in Figure 1. The conceptual framework being developed explains three direct relationships: the relationship between DMC and Service Excellence (SE), the relationship between SIC and SE, and the relationship between DMC-SIC and SE. The third relationship explains the interaction between $\mathrm{DMC}$ and SIC. The interaction between DMC and SIC is denoted with dashed lines and the direct relationship is denoted with solid lines.

\section{Dynamic Marketing Capability and Service Excellence}

Hotels are competing for the market share and develop new strategies to leave their competitors behind. In order to improve their image and increase their profit, hotels should put more effort into investigating the needs and expectations of their target groups. Only with a deep understanding of their customer's desires can the hotels keep their customers loyalty (Smolyaninova 2007). The study conducted by de Farias (2010) reveals that market sensing and learning play their roles as determining factors in service excel- lence. The evolutionary fit between market needs and market offers is the essence of effective service excellence. Sensing captures the effectiveness in order to generate, disseminate, and respond to customers' needs. Firms with higher absorptive capability demonstrate greater ability to learn, integrate external information, and transform it into their embedded knowledge (Hou 2008).

\section{Service Innovation Capability and Service Excellence}

Service innovation capability refers to a firm's ability to develop new services through aligning strategic innovative orientation with innovative behaviors and processes (Hou 2008). Meeting clients needs and providing innovative products are essential to deliver service excellence (Eisawi et al. 2012). Such activities as being able to identify the needs; to change, to explore, to select feasible opportunities; and to implement the new services in the organization are supporting factors in the hotel's service excellence. 


\section{Interaction DMC-SIC and Service Excellence}

The relationship between innovation and marketing has been acknowledged (Drucker 1954; Moorman and Slotegraaf 1999). Vorhies and Morgan (2005) showed that the effect of the combination of capabilities on results is greater, and complementary capabilities can increase a firm's effectiveness and/or efficiency (Milgrom and Roberts 1990; Moorman and Slotegraaf 1999; King et al. 2008). The studies to date have explored the effects of innovation and marketing capability, as well as their interaction on performance in manufacturing and service context (Ngo and O'Cass 2012; O'Cass and Ngo 2011; Sok and O'Cass 2011; Henard and Szymanski 2001; Im and Workman 2004). This study proposes that the interaction of DMC and SIC are determining factors for service excellence.

\section{The Hotel Industry in Indonesia}

The hotel industry in Indonesia has shown significant growth and has gained greater attention in today's business environment. The average growth rate of GDP in the hotel industry during 2004-2011 was 6.39 percent (www.bps.go.id) based on year 2000 constant price, compared to total Gross Domestic Product (GDP) at 5.84 percent. The hospitality sector became important when the government decided to further push the service sector. The average contribution of the hotel sector to total GDP based on year 2000 constant price within the 2004-2011 period amounted to 0.70 percent. The hotel industry is closely related to tourism. The tourism industry contributes the number of tourists who inhabit the hotels. The Indonesian Cen- tral Bureau of Statistics (www.bps.go.id) reported that there were 4.59 million foreign tourists in 2004 which had increased to 7.65 million in 2011. The revenue from international visitors has increased from US $\$ 4.80$ billion in 2004 to US\$ 8.55 billion in 2011. A similar trend can be seen in the number of hotels and the room occupancy rate (ROR). In 2004 there were 1,014 classified hotels (star hotels) and 9,847 nonclassified hotels (non-star hotels). These numbers had increased to 1,489 classified hotels and 13,794 nonclassified hotels in 2011. The room occupancy rate in 2004 for classified hotels was 44.98 percent and for nonclassified hotels 28.33 percent and these had increased to 51.25 percent and 38.74 percent respectively in 2011.

Though growing, the Indonesian hotel industry is facing new challenges due to external and internal factors in a business environment that affects their service excellence. External factors include intense competition from competitors. According to the Chairman of Indonesian Hotels and Restaurants Association (PHRI) of West Java, Mr. Herman Muchtar (personal communication, $27^{\text {th }}$ December 2010), the main issue related to the hospitality industry in Indonesia is the intense competition among star hotels and non-star hotels. This intense competition occurs because of the excess supply of hotels, regulations in terms of hotel development and service standards, and global competition where the hotels chains with an international network invest in new potential areas.

Currently, in order to survive, hotels in Indonesia perform with limited promotion, do not have a network or international cooperation with particular local hotels, and limited service innovation. To compete effectively, the hotel industry must be able to offer innovative services to visitors and pos- 
sess the proper promotion strategy in accordance with its market segment. The rise of low-fare airlines has impacted on the rise of budget hotels. The growth of the hotel business as a whole is currently positive, but budget hotels have the highest growth rate (Bloomberg Businessweek, 4-10 November 2013).

\section{Methods}

We collected data from 3 hotels. As it allows the questions of what, why, and how to be answered, we used the case study methodology (Yin 2003). Cases were selected from hotels based on a literal replication logic, that is, cases were chosen that were expected to lead to similar results (Yin 2003). According to Miles and Huberman (1994), a purposive sampling strategy was used to select cases that offered the best opportunities to build a theory. Our main criteria for case selection was based on: hotel star classification from 3-star to 5-star in an independent or chain network, and the key individuals have had considerable experience in the hospitality business with a wide variety of previous work. Of the hotels that we contacted, three hotels agreed to participate in the study. All of the hotels in our final list were tested by an expert to confirm that they fulfilled the 3-5 star hotel classification. Descriptions of the chosen hotels are provided in Table 1.
The primary data collection method was from interviews with the managers involved in the chosen hotels. The data were collected via semi-structured interviews using a research protocol (consisting of competition, dynamic marketing and service innovation capabilities, interaction, and service excellence) between September and December 2013. Overall, 3 interviews were conducted, typically lasting 1 to 1.5 hours each. Interviewees came from differing positions in the organizations, their job titles included general manager and sales director.

It is common in case research to use triangulation to extend and validate the data collection through the use of multiple sources of evidence (Eisenhardt 1989; Yin 2003). In the present study, this was done through the observation of and participation in some of the hotels studied. These were studied as a supplement to the interviews, enabling us to obtain further insights on the design approaches and to look for additional corroborating or contradicting evidence. We coded the inter-views using a predefined code list that was expanded during the analysis to capture emerging themes. The use of software and data coding makes qualitative data analysis procedures more systematic and guards against information-processing biases (Eisenhardt 1989; Miles and Huberman 1994). The coded interviews were then analyzed to identify support (or lack of support)

Table 1. Description of Sample

\begin{tabular}{lclclc}
\hline Name of Hotel & $\begin{array}{c}\text { Star } \\
\text { Category }\end{array}$ & $\begin{array}{l}\text { Key Individual } \\
\text { Position }\end{array}$ & $\begin{array}{c}\text { Experience } \\
\text { in Hotel }\end{array}$ & Network & Founded \\
\hline Golden Flower & 4 & Sales Director & 13 years & Local chain & 2009 \\
Grand Preanger & 5 & General Manager & 17 years & Local chain & 1920 \\
Aston Primera & 4 & General Manager & 26 years & International chain & 2009 \\
\hline
\end{tabular}


using software QSR N-Vivo 10. Specifically, we examined each case for evidence of the capability practices captured in the studies. To further ensure the accuracy and validity of the data, the results were written up in a report that was sent to all respondents for approval, to check that the conclusions accurately reflected their practices.

Operationalization of the variable is the process of translating or defining a variable so that it can be measured. Dynamic marketing capability, service innovation capability, and service excellence are operationalized and discussed below. Table 2 presents the variables operationalization and indicators. The DMC is operationalized through market sensing, learning, and target market/positioning. Market sensing is measured as the capacity to learn the external environment with respect to demands, customers, and competitors appropriately, the purpose of which is to guide a firm's actions (Day 1994). Learning is measured as the ability of the organization to implement the appropriate management practices, structures, and procedures that facilitate and encourage learning (Zollo and Winter 2002). Market targeting or positioning is measured as the ability to identify alternative opportunities before selecting appropriate market targets that are aligned for the best effect (Hooley et al. 2008).
The SIC is operationalized through sensing, seizing, and transforming. Sensing is measured as the activity to identify the need to change service operations and innovations. Seizing is measured as the activity to explore and select feasible opportunities for a change. Transforming is measured as the activity to implement the new services in an organization. All items for service innovation capability are based on Pöppelbuß et al. (2011).

Service excellence is operationalized through service delivery, servicescapes, customer' participation, and service responsiveness. Service delivery is measured as the method and sequence in which the service operating systems work to create the service experience and outcome (Bettencourt and Gwinner 1996). Servicescapes is measured as the style and appearance of the physical elements encountered by customers at service delivery sites (items based on Lovelock et al. 2005). Customer participation is measured as the actions and resources supplied by customers during service production and/ or delivery (Xue and Harker 2002). Service responsiveness is measured as the ability of a hotel to respond to individual guest's requirements (Gronroos 1982). 
Gadjah Mada International Journal of Business -May-August, Vol. 16,Na 2, 2014

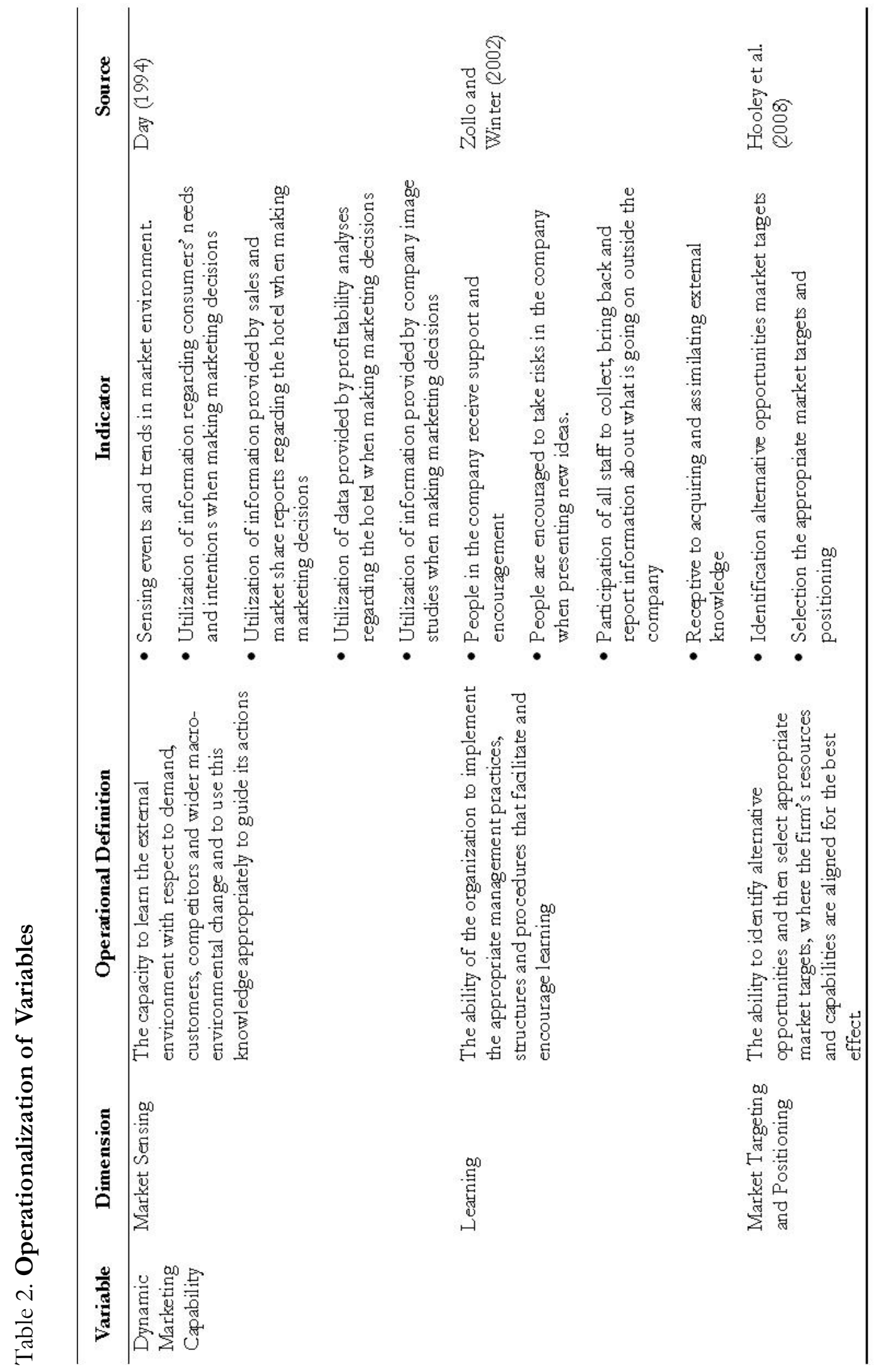


Hariandja et al.




Gadjah Mada International Journal of Business - May-August, Vol. 16,Na 2, 2014

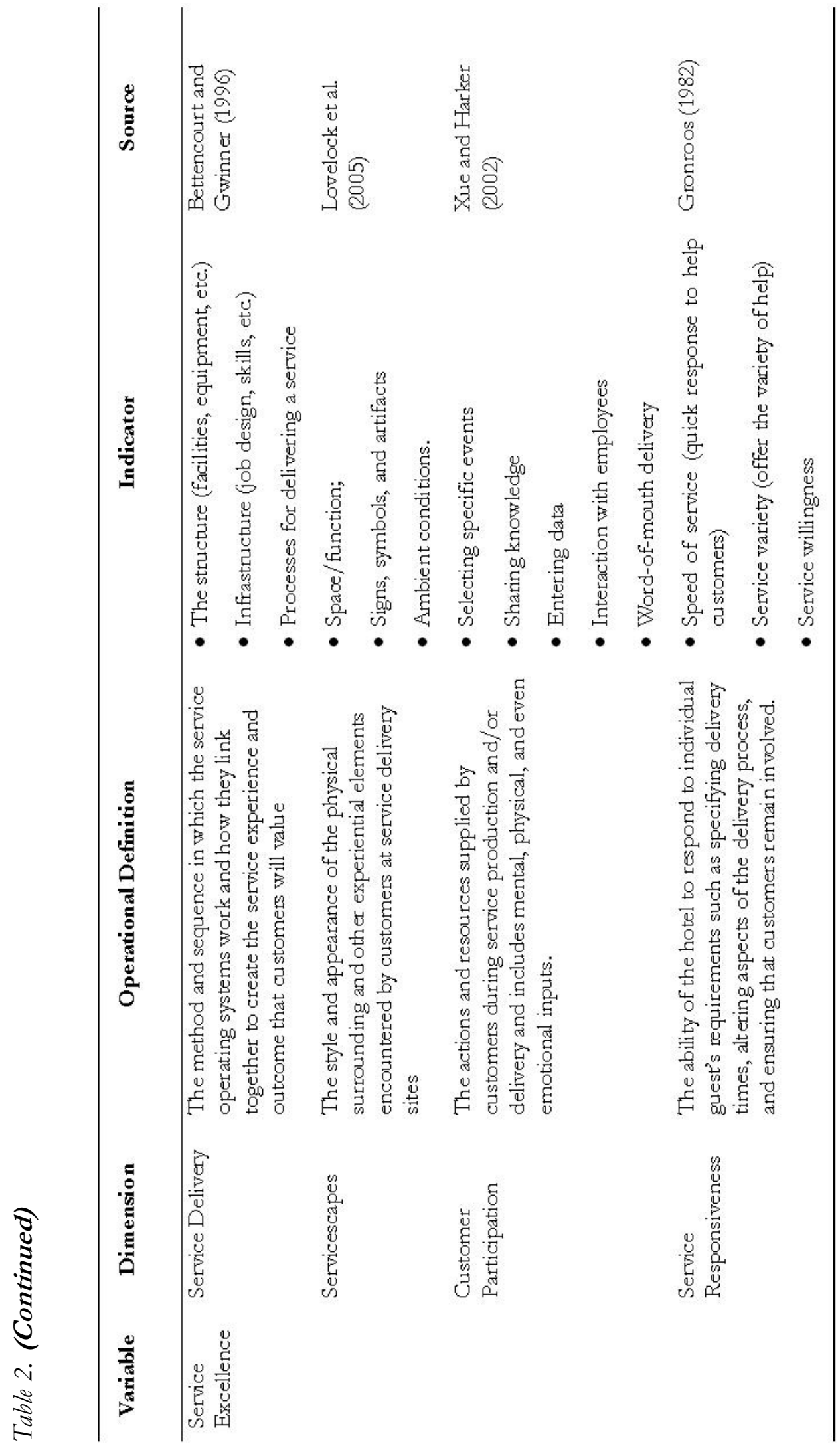




\section{Findings}

\section{Hotel A: Golden Flower}

The hotel was established on $1^{\text {st }}$ July 2009 as a 4-star local chain hotel under the Kagum Group. The hotel's strategy is to become the best convention hotel in Bandung by offering an affordable price. In the year 2014, there will be 52 chain hotels in Bandung, including the Royal Tulip, Santika, Swiss Belhotel, and Aston among others. The main competitors for Hotel A are the Savoy Homan, Aston Braga, Aston Primera, Grand Preanger, and Grand Royal Panghegar. In the midst of tight competition, the management remains optimistic and see the hospitality industry as still being prospective and profitable for the purpose of meetings and the weekend holidaymakers.

\section{DMC-Market Sensing}

The events and trends are regularly monitored through the PHRI (Indonesian Association of Hotels and Restaurants), competitors, telemarketers, and mass media. The issues include new hotel construction, promotion programs, building design, reservation and booking system technology. Customer's needs and intentions are explored through guest comments/feedback, thank you letters, and other media sources on a regular basis. Through guest comments, the hotels gain an insight, and can rapidly improve their services. Marketing decisions made across the Kagum Group and related hotels are done by exchanging the information regarding occupancy and the rooms being offered. Profitability analysis is performed by the sales and marketing department to be shared via email as an input into the decision making process. The hotel does not conduct an independent company' image study, but utilizes the "mys- tery guest method" and a services auditor. The mystery guest or services auditor will provide the results of his/her evaluation to the management for consideration in service improvements.

\section{DMC-Learning}

Hotel A provides training in self-development for its sales leaders and engages with staff in the marketing community. In regular meetings, the management gets feedback and ideas from staff for the hotel development. The staff members of the hotel are involved in the marketing plan and sales program activities. Departments such as F \& B, HRD, IT, front-office, and back-office participate in the information gathering about benefits, competitions, services, and designs. Hotel A applies technological developments in its online booking, data-base system, new promotions, and CRM.

\section{DMC-Market Targeting and Positioning}

Hotel A initially focused on government employees, members of parliament, and employees of local-government owned companies. Hotel A had a target market including government institutions, corporate bodies, and private companies/individuals, giving it a market share of 59 percent, 7 percent, and 34 percent, respectively two years ago. Currently, the government market share is 36 percent, corporate is 24 percent, and the private market is 40 percent. The corporate market is mostly oil and gas companies, such as Petro China and Chevron. The private market is from Malaysia, Singapore and the Middle East. The positioning of Hotel A is categorized as a perfect hotel for all your event requirements. 


\section{SIC-Sensing}

The innovation goal is to delight customers and minimize complaints. The marketing and sales department of the hotel are responsible for formulating strategic objectives and new services. The other departments are involved according to customers' needs and wants. The marketing, sales, housekeeping, and F \& B departments ask for the guests's comments regarding the appropriateness of food, beverage, and service supplied, with their expectations and SOP. The comments from digital sources, Trip Advisor, and the front-office enter the system and reach the top management. A regular audit is conducted in order to monitor the changes in customers' technological options and wants, such as providing 30 traditional dishes on the menu, the latest in design technology, and energy savings.

\section{SIC-Seizing}

The marketing and sales department of the hotel clearly define a new service, participants, support facilities, and tertiary physical changes tailored to the programs, events, and needs. The hotel's design factors are for a convention hotel. For example, its meeting rooms have 23 different layouts with the capacity for 20-500 persons, and are designed with a modern concept and equipped with modern equipment and advanced IT. Although some of the physical facilities are still limited, the hotel management has been trying to improve them. There are artists and contractors responsible for the design. The IT implementation is done by the head office of the Kagum Group. The promotional media, such as logos, fliers, and the layout are discussed and standardized with the head office. The service concept is assessed by a mystery guest with the management's ap- proval. The innovation evaluation involves off-line media, on-line media, and the clients.

\section{SIC-Transforming}

Before marketing the various services to guests, the marketing/sales department designs a prototype by involving relevant artists, designers, and maintenance staff to process flow, layout, design promotion, and maintenance facilities. The test marketing done for a new menu launching is with a cooking class, and at a special event, such as Eid, Christmas, or Independence Day. The service evaluation is conducted by auditors from the PHRI for overall aspects of the front-office, back-office, housekeeping, F \& B, and maintenance. The impact of the system integration is assessed regularly by the management of the Kagum Group.

\section{Interaction DMC and SIC}

The general manager of Hotel A stated that the interaction provides a more powerful influence on service excellence rather than that conducted partially through intense communication and coordination. The activities, such as an event promotion, personal selling, market research, market segmentation, advertising, and corporate branding are communicated directly to customers by marketing/ sales department. The activities, such as innovations in features and amenities (internet access, complementary shoe-shines, individual air conditioning, smoking and nonsmoking rooms, keyless rooms, uniforms), are communicated directly by the departments concerned and coordinated by the marketing/ sales department. The innovation activities are done according to both seasonal and market demands.

Theinteraction occurs in terms of menu development, price setting, selling, target 
market identification, promotions, and sales forecasting. For example, the F \& B department coordinates with the marketing department to test menus and evaluate prices according to market demands. If they fit the market, then the marketing department will communicate them to customers through brochures, leaflets, fliers, and banners to achieve service excellence. For IT-system implementation and room design, the marketing department interacts with the IT department, building management, and maintenance department before they are communicated to the customers.

\section{Service Excellence Comparison to Its Competitors}

The service excellence of Hotel A is similar to the Savoy Homan, Aston Braga, Aston Primera, and Grand Preanger. The servicescapes of the hotel is lower than its competitors due to its management is still improving the design and layout. Hotel A offers 193 exquisitely furnished guest rooms and luxurious suites equipped with excellent in-room amenities and entertainment. All of the hotel's function rooms are equipped with essential audio-video equipment, free internet access with Wi-Fi system is available in all areas of the hotel. There is a periodical customer participation program, particularly at such special occasions like Eid, school holidays, Christmas, or birthdays.

\section{Hotel B: Grand Preanger}

Hotel B was established in 1920 in the Dutch colonial era, and now it is managed by Aerowisata. Hotel B is a five star chain hotel. The aim of Hotel B is to be the perfect hotel where business and leisure, as well as graceful Sundanese hospitality, and the comfort of a modern business hotel blend. The current business competition is very tight and competitive, but the area still shows good prospects and good conditions. This competition is also enlivened by the presence of the affiliated chain and budget hotels such as the Accor, Aston and Swiss-Belhotel. In order to face that competition, the hotel's strategy is to grab both the MICE market and as at destination and activities promotion and selling place. The current average occupancy rate is around 50 percent- 60 percent.

\section{DMC-Market Sensing}

The sales department promotes destinations and explores the customer's opinions for its services. Hotel B regularly monitors such issues as: reservation system technology, the launching of a new hotel, social media, and building design through the PHRI, Riung Priangan, competitors, and mass media. The consumers' needs and intentions are surveyed via the guest's comments that are processed daily and weekly by the front-office department and then reported to general manager. The sales and market share reports are made across the group. The profitability analysis is performed by the sales and marketing department to be shared as an input into the decision making process. The hotel conducts its company's image study on a regular basis using the marketing consultants and Trip Advisor. During eight months in 2013, the hotel's rank increased from 54 to 22 (out of 120).

\section{DMC-Learning}

The management provides training for staff members, engages them in a marketing community, self-development activities, and sports. Getting feedback and ideas from the staff members is done by giving them vouchers, door prizes, and Employee of the Month awards in general staff meetings. The management encourages the staff members to get involved in the marketing plan and sales pro- 
gram activities to discuss such things as benefits, competition, services, design, and changes by their competitors. Hotel B uses technological developments in its on-line booking, customer data-base, new promotional strategies, CRM, and energy saving programs.

\section{DMC-Target Market and Positioning}

Hotel B mainly focuses its business on (government and parliament staff, state locally-owned companies) and leisure customers (European, Asian, and local tourists). Hotel B positions itself as the perfect hotel where business and leisure as well as 'artdeco' architecture and Sundanese hospitality blend. This selling point is communicated to their target customers.

\section{SIC-Sensing}

Hotel B sets its measurable, planned, and spontaneous innovation, and adapts it to fit the target market. The hotel emphasizes its innovation with its places of destination and activities program. Its strategic objectives and new services are formulated by its marketing department. Its marketing, sales, housekeeping and F \& B department ask for the guests's comments about whether or not the foods, beverages, and services meet with the customer's expectations and SOP. The comments from digital sources, Trip Advisor, and front-office enter the system and reach the general manager. A regular audit is conducted by a mystery guest and TUVRheinland. They regularly monitor changes in customers' wants both in technological options and in other areas, such as providing 10 types of coffee, local cuisines, a museum, in-room slippers, a "kiddy land" with a Tarsius icon, Sundanese uniforms for staff on Fridays, and energy savings.

\section{SIC-Seizing}

The hotel's marketing and sales department clearly define the new services, participants, support facilities, and tertiary physical changes tailored to the programs, events, and needs. Its design factors are tailored to capture the MICE market. For example, its meeting rooms have 12 different layouts with a capacity of 25-1000 persons, and are designed with a modern and 'art-deco' concept and equipped with the latest equipment and information technology. Selected designers are responsible for the interior design. IT-implementation is done by the head office of the Aerowisata Group. The hotel's ideas are promoted through logos and fliers, whose layouts are adjusted to the standards set by the Aerowisata Group and the nature of the target market. The concept of services is assessed by a mystery guest based on the hotel management's approval. In evaluating its innovation, Hotel B also involves internal parties, the mass media, and selected clients.

\section{SIC-Transforming}

The hotel's marketing and sales department design a prototype, involving designers and the maintenance department for such aspects as the process flow, layout, design promotion, and maintenance facilities. The hotel conducts marketing tests before launching new menus and special events, such as at: Eid, Christmas, Chinese New Year, New Year, and Independence Day. Overall, the hotel's service evaluation is conducted by auditors from PHRI and Riung Priangan. The impact of the system integration is assessed regularly by the management and Aerowisata Group. 


\section{Interaction DMC and SIC}

The general manager of Hotel B stated that the interaction between the dynamic marketing capability and the service innovation capability had a more powerful influence on service excellence. The interaction through intense communication and coordination involves all parties in the hotel. The activities such as event promotion, personal selling, market research, advertising, and branding are directly communicated to customers by the marketing department. For achieving its service excellence, the hotel's innovation activities features such amenities as internet access, complementary shoeshines, smoking and nonsmoking rooms, keyless rooms, staff uniforms, guest slippers, bolsters etc., and are communicated directly to customers according to both seasonal and market demands. The innovation activities are managed by the marketing department.

The interaction occurs in terms of the hotel's menu development, pricing, selling, target marketing, new services, promotions, and sales forecasting. The F \& B department will discuss with the marketing and sales department the testing of new menus and evaluate their prices according to the market demands. If they are a fit to the market, then the marketing department will communicate them to customers through brochures, leaflets, fliers, and banners. For the IT-implementation system and room design, the marketing department interacts with the IT department, building management and maintenance department to obtain the best system and design before communicating them to customers.

\section{Service Excellence Comparison to Its Competitors}

The service excellence of Hotel B is relatively better than that of the Savoy
Homan, Aston Braga, Aston Primera, Grand Royal Panghegar and Papandayan. Hotel B offers such features and amenities as $187 \mathrm{el}-$ egant art-deco furnished guest rooms from Superior to the Garuda Presidential Suite. Each of the hotel's guest rooms offers a blend of the art-deco and modern style, as well as excellent in-room amenities, and entertainment. The hotel's meeting and banquet facilities have 12 meeting rooms which can accommodate up to 1000 guests comfortably. All the hotel function rooms are equipped with audio-video equipment and a free WiFi system. Periodical customer participation occurs for special occasions like Eid, school holidays, Christmas, and birthdays.

\section{Hotel C: Aston Primera Pasteur}

Hotel C was established in 2009 as an international four-star chain hotel under the Aston Group. The vision of Hotel C is to become the best conference hotel in Bandung by offering different services and facilities. Its competitors are the Savoy Homan, Grand Preanger, Grand Royal Panghegar and new entries such as the Royal Tulip, Santika, and Swiss Belhotel. The interview results showed that the management remains optimistic and forsees that the hospitality industry will still be very profitable, with good prospects primarily from meetings and the weekend vacationers.

\section{DMC-Market Sensing}

The hotel's sales department regularly monitors the issues through the PHRI, its competitors, and the mass media. Consumers' needs and intentions are elaborated using REVINET tools covering such things as comments, ranking/position, and complaints. The guest's comments are processed and reported daily/weekly by the front-office department to the general manager to improve 
services. The reports of sales, market share, and profitability form the basis for marketing decision making. The reports gained from the Aston Group and their competitors are shared within the hotel. The hotel conducts a company' image study on a regular basis using consultants, outsiders, Agoda, and Trip Advisor. Currently, according to the survey from Agoda.com, overall, this hotel's rank is 7.9 (out of 10 points).

\section{DMC-Learning}

The management provides training to staff members, as much as 9 hours per staff member per month, and engages the staff members in its marketing community and selfdevelopment program. Feedback and ideas from staff members are elicited regularly during general meetings. The management encourages staff members to get involved in the marketing plans and sales program activities in which they discuss the benefits, competitions, services, designs, and opportunities operated by their competitors. The management is receptive to technological developments in its on-line booking, customer data base, new promotional strategies, CRM, and energy saving.

\section{DMC-Target Market and Positioning}

Hotel $\mathrm{C}$ mainly focuses on the market of MICE (both government institutions and corporate) and individuals (through non online travel agents and on-line travel agents). Its MICE market ranges from government institutions to oil and gas companies. It aims to position itself as the conference center that is secure and serves safe and hygienic food for both private companies and government institutions. This becomes the hotel's selling point to its customers.

\section{SIC-Sensing}

Hotel C sets discipline values consisting of operational excellence, product excellence, and customer intimacy. The hotel emphasizes its capabilities in the places of destination and activities markets. Its marketing department formulates the hotel's strategic objectives and new service developments. The hotel's innovation strategy is the differentiation in services and facilities. The marketing, sales, housekeeping and F \& B departments ask for the guests' comments about whether or not the food, beverages and services match their expectations and SOP. The comments from digital media, Trip Advisor, and front-office enter the system and are passed to the general manager. Both the service and ISO-9001 audit are conducted regularly. The service audit was last conducted by a mystery guest, while the ISO9001 was conducted by an ISO-9001 auditor. Monitoring changes in customers' desires and technological options is done by conducting such activities as "little chef for kids" with a certificate, tours of the hotel, and exhibitions of modern and local cuisines.

\section{SIC-Seizing}

The hotel's marketing department coordinates with the sales department to clearly define its new services, participants, support facilities, and tertiary physical changes tailored to its programs, events, and needs. Its design factors are tailored to the target market by using advanced technologies, for example audiovisual equipment. There are designers appointed who are responsible for the interior and exterior design. The IT-implementation is done by the head office. The ideas for new menus and new activities are promoted through logos, fliers, and layouts after 
they are adjusted to the nature of the target market. The concept of the hotel's services is assessed by outsiders and auditors from the Hospitality Asia Platinum Awards (HAPA) scheme. In the period from 2012-2014, Hotel C achieved "Best 5" and "Recognition of Excellent Master Chef and Asian Cuisine". In evaluating its innovations, Hotel $\mathrm{C}$ involves internal parties, the mass media, and selected clients.

\section{SIC-Transforming}

The hotel's prototype designs such as the process flow, layout, promotion, and amenities are conducted by its marketing and sales department together with its designers. The hotel also conducts market tests before launching its new menus and special events. Overall, the services of the hotel are evaluated by auditors from the PHRI, HAPA, and Riung Priangan. The impact of its service system integration is assessed regularly by the management and the Aston Group.

\section{Interaction DMC and SIC}

The interaction between DMC and SIC provides a more powerful influence on service excellence through intense communication and coordination. Such activities as promotion, personal selling, market research, advertising, and branding conducted by the marketing and sales department are then communicated directly to customers. The innovation activities in its features and amenities (internet, complementary shoe-shines, keyless rooms) are conducted by the department in charge according to both seasonal and market demand for service excellence. These innovations activities are managed by the marketing department.

The interaction occurs in such activities as IT-implementation, management system building, menu developments (little chef, barbeque night on a Friday), air soft-gun and hiking programs, pricing, selling, target market identification, promotions, and sales forecasting. For menu development, the F \& B department coordinates and shares the information with the marketing and sales department to test the new menus before they are communicated to customers through talk shows, brochures, leaflets, fliers, and banners.

\section{Service Excellence Comparison to Its Competitors}

The service excellence of Hotel $C$ is relatively better than the Grand Aquila, Savoy Homan, BTC Hotel, Grand Royal Panghegar, Papandayan and Sensa Hotel. In terms of features and amenities, Hotel $\mathrm{C}$ offers modern and excellent technology. The hotel's meeting and banquet facilities have 12 meeting rooms which can accommodate up to 1500 guests comfortably. All the hotel function rooms are equipped with audiovideo equipment and a free Wi-Fi system. There is periodical customer participation on special occasions like Eid, school holidays, Christmas, and birthdays.

\section{Discussion}

The findings of the three hotels are summarized in Table 3. The market sensing in all the case studies used the guests comments, sales reports, and profitability analyses to sense the trends and events in the market which are then used as the basis for marketing decision making. The information exchange is done with the competitors, the PHRI, Riung Priangan, Trip Advisor and Agoda. The general manager monitors customers' wants and complaints by using different IT-systems. This market sensing allows the hotel to respond to customers quickly, to deliver the best service by involving the cus- 
tomers, and to offer the best facilities according to customer expectations.

Market target or positioning of one hotel is different from another and has its own unique differentiation. The Grand Preanger Hotel, for example, is focused on being at heritage hotel for tourists especially from the European, Japanese and Indonesian markets. The Aston Primera is more focused on the big oil, gas, and mining companies. The Golden Flower focuses on its convention business, and on tourists from Southeast Asian countries. The ability of each hotel to sort the appropriate segments and communicate its own positioning in the minds of customers makes the service delivery of each hotel match its target market. By engaging customers and responding quickly to fulfill their expectations, each hotel achieves its own desired service excellence.

Each hotel has a different strategy in serving their customers. Each hotel's innovation strategy formulation and new service development are mostly done by its own department of marketing, sales, housekeeping, and F \& B. Other departments are involved when they are relevant to the events and occasions. Most of the innovations in the three hotels concern the menu development. Regular audits are conducted by inviting outsiders to assess the overall services offered, to anticipate changes in customer's needs, and to evaluate whether the technological options are in accordance with the SOP and customers expectations.

The innovation made by Hotel B is to provide a heritage museum and the implementation of eco-green policies, while the innovation made by Hotel $C$ is to conduct its "Little Chefs" and air soft-gun programs. Sensing activities allows hotels to formulate different innovation strategies that can re- spond to customers and deliver their services to them. Appropriate service delivery and offering the best servicescapes by involving customers will ultimately achieve service excellence in terms of meeting customer expectations.

Based on the interview sessions from three key personnel of the hotels, the three case studies indicate that interaction between DMC and SIC is a more powerful influence in order to achieve service excellence. Through the intense communication and coordination in which all departments of the hotel are involved, service excellence will be achieved. In order to achieve service excellence, activities such as market research, direct selling, event promotion, and corporate branding, marketing, and spontaneous innovations like amenities, according to seasonal and market demand, are communicated directly to customers. The capability interaction occurs mostly in the menu development, event development, price setting, price comparison, and selling.

All three hotels represent interesting examples of how both capabilities interact with each other in achieving service excellence. Even though each hotel follows its own marketing and innovation strategy, some commonalities in all their strategies are found. Some general conclusions can be drawn from this study, such as: the learned valuable lessons about marketing strategy, innovation strategy, and interaction between their capabilities. The conceptual framework for analyzing the cases was developed based on various theories and models about capabilities of dynamic marketing and service innovation found in various literature sources. The results of the study suggest that capabilities interaction has more influence on service excellence. 
Hariandja et al.

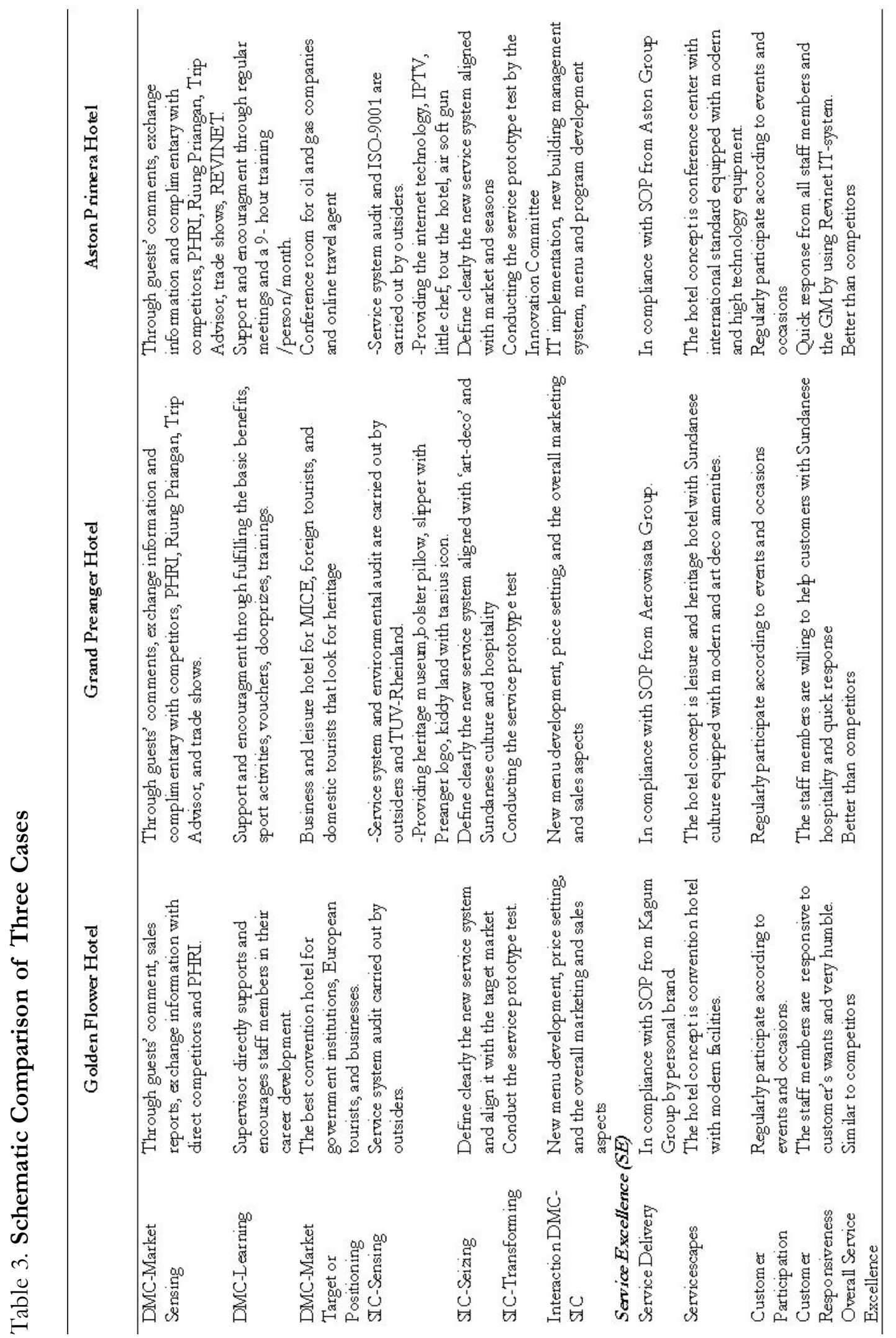


This study offers an interesting view for the management of hospitality firms. The reason is that the existing service excellence frameworks are mainly based on both dynamic marketing and service innovation capability as well as their interaction, and therefore these frameworks have a limited application potential in a hospitality context. All of the six activities are usable in hotels. The various ways to make marketing strategies achieve service excellence are also illustrated in this study. General managers in hotels can use the proposed 6 different activities for both capabilities as a list of options to affect their hotels' service excellence. From this list, the general managers can then select the activities that suit their hotels' needs and service excellence. Hotels have some complex elements, and their service excellence may depend on these various elements, or their interaction. These case studies show that service excellence starts with building the associations of both capabilities. A hotel's brand successfully positioned in the consumers' minds will become an asset of the company that contributes to its service excellence. To conclude, the results of these case studies are limited to the hotel industry only.

\section{Conclusions}

This study reveals that there is a relationship among dynamic marketing capability, service innovation capability, both capabilities interaction, and service excellence. The key informants stated that a dynamic marketing capability and a service innovation capability partially affected service excellence, but this relationship had more influence when the dynamic marketing capability and service innovation capability interacted. The conceptual model described in this study is to examine the basis of a direct relationship between the dynamic marketing capa- bility, the service innovation capability, and their interaction with service excellence.

The results of the study indicate that the dynamic marketing capability, the service innovation capability, and their interaction in the three hotels show some similarities. The difference lies in the marketing strategies and innovation strategies, which are tailored to the target markets and occasions. The service excellence is strongly influenced by how each of the hotels is able to sense trends and events, respond to the market demands through the learning process, identifies their right target market, and communicate with their customers. The service excellence is achieved by defining the services, participants, and physical facilities clearly; continuously performing the audit services; and test the prototypes. The capabilities interaction are mostly determined by the marketing departments and the sales by involving other relevant departments.

This exploratory research does not seek to draw statistical inferences, therefore is subject to the following limitations arising from the case study methodology. First, the application of the interaction between dynamic marketing capability and service innovation capability in hotels is limited to major cities in Indonesia alone. Second, the coverage of sampling and findings are based solely on the three unique classified hotels (4 and 5 starhotels), which may not be generalizable to the other classified hotels $(1,2$, and 3 starhotels), nonclassified hotels, and in the rural areas. Third, Hotel $\mathrm{C}$ was very reluctant to provide its company profile compared with Hotel A and B. In the end, in order to complete the analysis the general manager of Hotel C finally provided that company's profile through their marketing department and human resources department after confirmation from the authors. 
Further research could apply this developed conceptual framework to analyze hotels beside 4 and 5 star hotels. Therefore, research on other industries (financial service, airlines, consulting, etc.) possessing interaction capabilities is needed, by combining it with quantitative (confirmatory) research. From the case studies, the strong brand names of the two hotel seemed to contribute to their service excellence. It is recommended that further research on the relationship between the capabilities interaction and service excellence to the hotel performance should be done.

From a managerial perspective, this study expected to contribute to the develop- ment of a conceptual model linking dynamic marketing capability, service innovation capability, and the capabilities interaction in order to achieve service excellence in the hotel industry. In practice, this study is aimed at helping the hospitality industry to better plan and move towards effective and intense dynamic marketing and greater service innovation implementation. This study will hopefully provide insights on some of the factors of dynamic marketing capability and service innovation capability which would assist the hospitality industry to create the appropriate environment to encourage the promotion of service excellence and customer satisfaction and finally customer loyalty.

\section{References}

Atuahene-Gima, K. 1996. Market orientation and innovation. Journal of Business Research 35 (2): 93-103.

Aziz, Y.A., and K. Wahiddin. 2010. Conceptualising the service excellence and its antecedents: the development of the structural equation model. Journal of Tourism, Hospitality and Culinary Arts 2 (1): 113.

Bäckstrand, J. 2007. Levels of interaction in supply chain relations. Unpublished PhD Thesis. Göteborg, Sweden: Chalmers University of Technology.

Berry, L. L., and A. Parasuraman. 1992. Prescriptions for a service quality revolution in America. Organizational Dynamics 20 (4): 5-15.

Bettencourt, L. A., and K. Gwinner. 1996. Customization of the service experience: the role of the frontline employee. International Journal of Service Industry Management 7 (2): 3-20.

Day, G. S. 1994. The capabilities of market-driven organization. The Journal of Marketing 58 (4): 37-61.

de Farias, S. A. 2010. Internal marketing (IM): A literature review and research propositions for service excellence. Brazilian Business Review. Vitória (7) (2) (May-August): 99-115.

Drucker, P. F. 1954. The Practice of Management. New York: Harper and Brothers.

Dube, L., and L. M. Renaghan. 2000. Creating visible customer value - how customers view best-practice champions. The Cornell Hotel and Restaurant Administration Quarterly (40) (7): 62-72.

Eisawi, D. A., H. Sekhon, and S. Tanna. 2012. Innovation as a determinant for service excellence in banking. International Journal of e-Education, e-Business, e-Management and e-Learning 2 (4): 336-338.

Gadrey, J., F. Gallouj, and O. Weinstein. 1995. New modes of innovation: How services benefit industry. International Journal of Service Industry Management 6 (3): 4-16. 
Garud, R., and P. R. Nayyar. 1994. Transformative capacity: Continual structuring by intertemporal technology transfer. Strategic Management Journal 15 (5): 365-85.

Grönroos, C. 1982. An applied service marketing theory. European Journal of Marketing 16 (7): 30-41.

Henard, D., and D. Szymanski. 2001. Why some new products are more successful than others. Journal of Marketing Research 38 (3): 362-375.

Heskett, J. L., W. E. Sasser, and L. A. Schlesinger. 1997. The Service Profit Chain. New York: The Free Press.

Hooley, G. J., N. Piercy, and B. Nicoulaud. 2008. Marketing Strategy and Competitive Positioning. London: FT Prentice Hall.

Hou, J. J. 2008. Toward a research model of market orientation and dynamic capabilities. Social Behavior and Personality 36 (9): 1251-1268.

Hult, G. T. M., and D. J. Ketchen Jr. 2001. Does market orientation matter?: A test of the relationship between positional advantage and performance. Strategic Management Journal 22 (9): 899-906.

Im, S., and J. Workman. 2004. Market orientation, creativity, and new product performance in hightechnology firms. Journal of Marketing 68 (2): 114-132.

Johnston, R. 2004. Towards a better understanding of service excellence. Managing Service Quality 14 (2/3): 129-133.

King, D. R., R. Slotegraaf, and I. Kesner. 2008. Performance implications of firm resource interactions in the acquisition of RandD-intensive firms. Organization Science 19 (2): 327-340.

Kok, R., B. Hillebrand, and W. Biemans. 2003. What makes product development market oriented? Towards a conceptual framework. International Journal of Innovation Management 7 (2): 137-162.

Lovelock, C. H., H. T. Keh, X. Lu, and J. Wirtz. 2005. Services Marketing in Asia: Managing People, Technology, and Strategy ( $2^{\text {nd }}$ ed.). Singapore: Prentice Hall.

Milgrom, P., and J. Roberts. 1990. The economics of modern manufacturing: Technology, strategy, and organization. The American Economic Review 80 (3): 511-528.

Moorman, C., and R. J. Slotegraaf. 1999. The contingency value of complementary capabilities in product development. Journal of Marketing Research 36 (2): 239-257.

Ngo, L. V., and A. O'Cass. 2012. In search of innovation and customer-related performance superiority: The role of market orientation, marketing capability and innovation capability interactions. Journal of Product Innovation Management 29 (5): 861-877.

O'Cass, A., and L. V. Ngo. 2011. Winning through innovation and marketing: lessons from Australia and Vietnam. Industrial Marketing Management 40 (8): 1319-1329.

Oliver, R. L. 1997. Satisfaction: A behavioural perspective on the consumer. New York: Irwin/Mc Graw Hill.

Pöppelbuß. J., R. Plattfaut, K. Ortbach, A. Malsbender, M. Voigt, and B. Niehaves. 2011. Service innovation capability: Proposing a new framework. Proceedings of the $3^{\text {rd }}$ International Symposium on Services Science (ISSS) in conjunction with the Federated Conference on Computer Science and Information Systems (FedCSIS), Szczecin, Poland.

Smolyaninova, J. 2007. Hospitality market opportunities for the business market segment in Borlänge. Unpublished Master's Thesis. Bournemouth University, Bournemouth, United Kingdom.

Sok, P., and A. O'Cass. 2010. Examining the interactive roles of marketing, innovation and social networking capabilities on firms customer-based performance. ANZMAC (November 29-December 1). Christchurch, New Zealand. 
Sok, P., and A. O'Cass. 2011. In search of financial performance superiority via product and customer performance outcome: The role of complementary resource-capability combination within and between innovation and marketing areas. International Conference of Decision Science (July 12-July 16). Taipei, Taiwan.

Song, M., S. Hanvanich, and R. Calantone. 2005. Marketing and technology resource complementarity: An analysis of their interaction effect in two environmental contexts. Strategic Management Journal 26 (3): 259-276.

Teece D. J., G. Pisano, and A. Shuen. 1997. Dynamic capabilities and strategic management. Strategic Management Journal 18 (7): 509-535.

Tekes. 2009. Serve - Innovative Services Technology Programme 2006-2010.

Thomson, J. D. 1967. Organisations in Action. New York: McGraw-Hill.

Tushman, M., and C. O’Reilly. 1997. Winning Through Innovation: A Practical Guide to Leading Organizational Change and Renewal. Boston, MA: Harvard Business School Press.

Vorhies, D. W., and N. A. Morgan. 2005. Benchmarking marketing capabilities for sustained competitive advantage. Journal of Marketing 69 (1): 80-94.

Winter, S. G. 2003. Understanding dynamic capabilities. Strategic Management Journal 24 (10): 991-995.

Xue, M., and P. T. Harker. 2002. Customer efficiency: Concept and its impact on e-business management. Journal of Service Research 4 (4): 253-267.

Zollo, M., and S. G. Winter. 2002. Deliberate learning and the evolution of dynamic capabilities. Organization Science 13 (3): 339-351.

\section{Newspaper:}

Prospek budget hotel cerah. (2013, 4-10 November). Bloomberg Businessweek: 6.

\section{Websites:}

Statistics of Indonesia: Tourism. Http://www.bps.go.id/eng/menutab.php?tabel=1andkat= 2andid_subyek $=16$. Accessed the $16^{\text {th }}$ April 2013, at 10.25 . 
